\title{
Anti-vaccine movements - a form of social activity for health care, ignorance or diversion aimed at destabilizing the health situation? Part 1. Epidemiological safety. Vaccinations - pros and cons
}

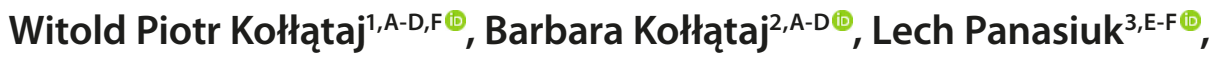 \\ Jarosław Sobieszczański ${ }^{4, B-C \oplus}$, Irena Dorota Karwat ${ }^{5, B-C, E \oplus}$ \\ ${ }^{1}$ Department of Paediatric Endocrinology and Diabetology with Endocrine - Metabolic Laboratory, Medical University, \\ Lublin, Poland \\ ${ }^{2}$ Chair and Department of Epidemiology and Clinical Research Methodology, Medical University, Lublin, Poland \\ ${ }^{3}$ Institute of Rural Heath, Lublin, Poland \\ ${ }^{4}$ Chair and Department of Conservative Dentistry with Endodonthic. Medical University, Lublin, Poland \\ ${ }^{5}$ Medical Institute, Jan Grodek State University, Sanok, Poland \\ A - Research concept and design, B - Collection and/or assembly of data, C - Data analysis and interpretation, \\ $D$ - Writing the article, E - Critical revision of the article, F - Final approval of article
}

\begin{abstract}
Kołłątaj WP, Kołłątaj B, Panasiuk L, Sobieszczański J, Karwat ID. Anti-vaccine movements - a form of social activity for health care, ignorance or diversion aimed at destabilizing the health situation? Part 1. Epidemiological safety. Vaccinations - pros and cons. Ann Agric Environ Med. 2020; 27(4): 544-552. doi: 10.26444/aaem/126013
\end{abstract}

\begin{abstract}
Introduction. Vaccinations are a way accepted by science of preventing infectious diseases. Because of their epidemiological significance, vaccinations are considered compulsory in many countries and their evasion is penalized. Anti-vaccine movements may pose a threat to the epidemiological situation in many countries. The study presents the arguments formulated by opponents of vaccination and provides counter-arguments.

Materials and method. The study is based on the analysis of data stored in scientific databases, information obtained from Google, Bing and Yahoo on the Internet, as well as newspapers, magazines and opinion-forming websites.

Results. The slogans propagated by anti-vaccination movements are usually based on easily proven erroneous theories and lies, although there are also arguments expressing belief in the conspiracy of governments, politicians and vaccine manufacturers, or incompetence of scientists and practitioners.

Conclusions. In recent years in Poland, the activity of movements against vaccination has increased significantly, and their propaganda, through its negative impact on social attitudes, threatens to destabilize the epidemiological situation. Analysis of arguments used by the opponents of vaccination suggests a lack of reliable knowledge, religious overtones (addressed to people with fundamentalist personalities), or the ill-will attitudes of anti-vaccine individuals/groups used for their own purposes. Familiarization with the arguments of anti-vaccine propaganda is necessary in order to implement effective methods of fighting such attitudes and beliefs.
\end{abstract}

Keywords

vaccinations, argumentation, vaccine opponents, religious arguments, misinformation, safety of vaccination

\section{INTRODUCTION}

Vaccination is a science-approved method of combating infectious diseases and consists of administering a biological preparation (vaccine) which is supposed to cause an immune effect similar to that ocurring during natural infection. It leads to the development of identical immunity that the body obtains during the first contact with an infectious agent (bacterium or virus). This protects the body against the disease, protects against the adverse pathophysiological effects of diseases, and against their possible complications

Address for correspondence: Witold Piotr Kołłątaj, Department of Paediatric Endocrinology and Diabetology with Endocrine - Metabolic Laboratory, Medical University, Lublin, Poland

E-mail:wk@data.pl

Received: 25.05.2020; accepted: 02.08.2020; first published: 26.08.2020 (death / shortening of survival time, disability, deterioration of quality of life). Taking into account the well-being of the entire population, vaccinations have an impact on extending life expectancy, reducing the number of complications of infectious diseases, including reducing the scale of disability, improving the quality of life of the population, saving (reducing sickness absence, reducing expenditure on the treatment of diseases and their consequences) and adjusting the epidemiological risk level to $\mathrm{WHO}$ and $\mathrm{EU}$ requirements.

From a population perspective, the goal of vaccination is to achieve community resistance to disease by vaccinating a high percentage of people among the population. This objective applies to diseases that are spread between people (not infectious diseases such as tetanus or rabies). Population security is ensured if the so-called community resistance threshold (i.e. the percentage of people vaccinated in the population that 
allows a reduction in the number of new infections) is reached. For most infectious diseases, this threshold is between 90 $94 \%$, i.e. when $90-94 \%$ of the population has immunity [1]. However, the percentage of people who should be vaccinated varies depending on the disease.

It is estimated that the lower measles threshold for community immunity is between $90 \%-94 \%, 90-94 \%$ for pertussis, $86-93 \%$ for mumps, $86-91 \%$ for smallpox, $75-80 \%$ for diphtheria and $80-86 \%$ for polio [1]. These estimates were prepared by institutions dealing with epidemiological safety and may differ, depending on the country. For example, in the United States, the Department of Health and Welfare that develops healthy theses for 2020 (National Targets for Vaccinating Healthy People 2020, US) [2] suggests that the vaccination rate of $90 \%$ (or $85 \%$ in the case of hepatitis $A$ and $\mathrm{B}$, as well as $80 \%$ in the case of rotavirus diarrheas) in children aged 19-35 months provides sufficient protection against most diseases that are preventable through the use of preventive vaccinations. Currently available vaccines protect people against 26 infectious diseases.

Vaccinology in historical terms. Vaccination, as an effective prophylaxis of the spread of infectious diseases, appeared in the eighteenth century; therefore, the entire current development of vaccinology has been known for only 224 years. The first vaccine used globally in humans was the smallpox vaccine invented by British physician Edward Jenner in 1796 . He vaccinated an 8 -year-old boy with a vaccine which contained live cowpox viruses, administered by scarification [3]. After vaccination, the boy had the symptoms of a mild infectious disease but also acquired smallpox immunity. Despite the successes in the fight against this disease, some countries have not carried out vaccinations against smallpox (e.g. India, where poverty and lack of financial possibilities to carry out this type of action was the reason for the neglect of vaccines).

In the 1950s, about two million people were dying of smallpox, but it was not until 1967 that an international team of doctors was appointed to fight the disease. Under the leadership of the American Donald Henderson, the team started vaccinations using the ring method of vaccinating the population affected by newly-detected outbreaks of smallpox [3]. As a result of the systematic vaccination of the world population on 9 December 1979, the World Health Organization confirmed the eradication of smallpox worldwide. This success was officially announced in May 1980 [4]. Although vaccination against smallpox led to the complete eradication of this disease [5], other diseases against which vaccines have been produced remain a constant threat.

Another milestone in the development of vaccine therapy was the use of the rabies vaccine invented in 1885 by the French chemist Louis Pasteur. He successfully vaccinated a 9-year-old boy who had been bitten by a rabid dog [6]. The next achievements in the field of vaccinology were the implementation of tuberculin by German bacteriologist Robert Koch in 1890, and in the same year the preparation of a diphtheria and tetanus serum [7] by Emil Behring in Germany and Shibasaburō Kitasato in Japan. Two years later, the French bacteriologist Waldemar Haffkine invented the cholera vaccine [7]. In 1896, the British Almroth Wright and German Richard Pfeiffer invented the typhoid fever vaccine $[8,9]$.

At the beginning of the twentieth century, in 1910, Polish biologist Rudolf Weigl applied the world's first effective typhus vaccine based on rickettsiae multiplied in living lice organisms [10]. In 1921, the French vaccine TB (Bacillus Calmette-Guérin) invented by the Frenchmen Albert Calmette and Camille Guérin, was used for the first time [11]. Two years later, the Frenchman Gaston Ramon and Alexander Glenny in Britain developed a diphtheria vaccine [7]. The same year, American doctor Max Theiler invented a method for the preparation of a pertussis vaccine and a year later used it during an epidemic on the Faroe Islands [7]. In France in 1927, Gaston Ramon and Christian Zoeller from the Pasteur Institute in Paris developed a tetanus vaccine [12] and 10 years later, the American Max Theiler developed a yellow fever vaccine [7].

It was not until 1941 that the American Jonas Salk started vaccination with influenza A vaccine [7], and in 1950, Polish physician, virologist and immunologist Hilary Koprowski developed the first oral vaccine containing live attenuated virus against common paralysis. The first mass vaccination took place in 1958 in the Congo [13]. Two years later, Jonas Salk first used an injection vaccine containing dead polio viruses [14]. In 1954, Albert Sabin developed a new oral polio vaccine containing attenuated live virus strains [15]. Ten years later, tests began with a measles vaccine developed by the American John Enders [16]. In 1967, vaccination against mumps began with a vaccine developed by the American Maurice Hilleman, who had isolated the virus in 1963 [17]. A year later, the American Emil Gotschlich developed a vaccine against group $\mathrm{C}$ meningococci and in 1971 a vaccine against group A meningococci [7]. In 1967, Maurice Hilleman also developed a vaccine for the prevention of rubella [18]. In 1974, the Japanese Michiaki Takahashi developed the chickenpox vaccine [18], and five years later Maurice Hilleman and colleagues developed two hepatitis A vaccines, one containing dead and the other attenuated viruses. In 1980, Hilleman introduced the Haemophilus influenzae type B vaccine for prophylaxis, and in 1981 the hepatitis B vaccine containing an HBs surface antigen [7]. In 1998, the first rotavirus vaccine was applied [19]. In 2006, the human papillomavirus vaccine was licensed [18].

Although the concept of vaccination only appeared in the eighteenth century, the development of modern vaccinology was carried out in the twentieth and twentyfirst centuries. According to experts, 122 million people owe their lives to vaccinations since Jenner introduced the first smallpox vaccine. Every year, around one billion vaccines are administered around the world that save the lives of around 2.5 million people [5].

Vaccinations - benefits and safety. Vaccinations not only prevent infectious diseases, they also prevent the development of certain cancers: the hepatitis $B$ vaccine protects against hepatocellular carcinoma [20], and the human papillomavirus vaccine protects against cervical cancer in women, cancer of the anus, head and neck, as well as cancers of the male genitalia [21]. Vaccination against bacterial diseases also prevents the development of bacterial antibiotic resistance [5]. Vaccination does does not provide $100 \%$ protection against infectious agents. The effectiveness of vaccines depends on the one hand on the choice and method of production of antigenic materials and adjuvants, on the other hand, on the dose of antigen, treatment regimen used and effectiveness of the immune system of the vaccinated person (and thus indirectly on concomitant diseases and treatment, nutritional 
status, age of the patient and specific circumstances, such as prematurity or recovery after other illnesses).

Because vaccination is an obvious interference in the functioning of the human body, its use raises both public interest and often fears (as with any interference in the functioning and integrity of the human body). Fears are fueled by the fact that vaccinations are not always effective - hence the questions about the sense of such interference in living organisms. Insufficient vaccine efficacy can be due to many reasons: it can depend on the antigen dose, the individual properties of the patient's immune system. Sometimes it results from breaking the rules related to the storage of the vaccine, as well as the treatment regime. Vaccination can also cause adverse reactions, which raises the question of whether the benefits and potential risks of medical treatment are properly balanced. Such doubts have accompanied vaccines for decades and were particularly justified when vaccines were of inferior quality, insufficiently tested, and contraindications for vaccination were not precisely determined and taken into account. Side-effects resulted that resembled the clinical course of the diseases that were supposed to be protected by vaccines, as well as post-vaccination complications identical to those observed in patients who underwent a full-blown infectious disease.

In Poland, after vaccination with the live oral poliovirus vaccine (OPV) in 1960, there were cases of paralytic polio associated with vaccination, currently called VAPP, caused mainly by the type 3 virus. These diseases caused the suspension in 1961 of oral vaccination with type 3 poliovirus in Poland. Until 1967, the polio vaccination programme had also included the administration of two doses of the multivalent inactivated Salk vaccine. In 1967, this type of vaccination was withdrawn. The following year, vaccination with a live oral vaccine against poliomyelitis type 3 , recommended by the $\mathrm{WHO}$, was introduced. However, during this vaccination programme, a poliomyelitis epidemic broke out, and in 1968, a total of 464 cases and 17 deaths were recorded in Poland, 341 cases were caused by the type 3 virus (73.5\%) [22]. Withdrawal of the type 3 virus and implementation of a new OPV vaccine increased the safety of vaccination.

Since April 2016 in Poland, vaccinations against poliomyelitis are carried out only with an inactivated poliovirus vaccine (IPV) containing three types of dead strains of polioviruses- a vaccine developed by J. E. Salk [23]. This vaccine is for intramuscular administration. Although this vaccine guarantees full safety, the fears remained and are articulated because, as one can assume, the problem has not been sufficiently publicly explained, and the changes in antigen material used as vaccine have not been well publicized.

Today, more and more effective and safer vaccines are available to fight infectious diseases and should help in the elimination of many of them. Unfortunately, there are still many obstacles that make it difficult to minimize the epidemic threat, including anti-vaccine movements, which pose a real threat to the successful implementation of vaccination programmes, not only in Poland but worldwide.

\section{OBJECTIVE}

The aim of the study is to present the current epidemiological context of opposition to vaccination and the arguments against it, including propaganda referring to religious aspects, and to present counter-arguments.

In the near future, attitudes towards vaccination may become an important factor impeding the fight against pandemics caused by the SARS-CoV-2 virus, not only in Poland but around the world. Today, when there is no effective vaccine yet, the statements "I do not want to be vaccinated against COVID-19" appear in the mass media. Such opinions voiced by people who have a large impact on public opinion are dangerous and must be stigmatized, but in order to criticize and fight such attitudes, it is necessary to understand the broad context of this phenomenon.

\section{MATERIALS AND METHOD}

The study is based on the analysis of published information on vaccinations and articulated concerns related to the safety, legitimacy, and obligation of preventive vaccination, especially in the context of the slogans of the personal freedom of citizens.

Data on epidemiological safety, vaccinations, vaccines, vaccination complications, and threats arising from the uncontrolled flow of information in cyberspace were obtained from database materials: NCBI (The National Center for Biotechnology Information), MEDLINE / PubMed created by the National Library of Medicine in the USA, Science Direct Web of Science, Springer, Medline Complete and Web of Science, as well as official information published by vaccine manufacturers and institutions dealing with vaccination safety and epidemiological supervision (National Institute of Public Health-PZH, Chief Sanitary Inspector in Poland, European Center for Disease Prevention and Control (ECDC), and Reports by the EU Commissioner for Health and Food Safety). Materials in Polish and English were analyzed.

Data on attitudes and arguments formulated by opponents of vaccination were searched for in the above-mentioned databases, as well as in the Internet resources accessed by search engines Google, Bing and Yahoo (public press, websites of newspapers and magazines and opinion-forming websites). Additional sources of information were the applicable EU legal acts published on the European Union portal - EU Law and Reports of the European Commission.

\section{RESULTS}

Problems of prophylaxis of infectious diseases in Poland - deteriorating state of vaccination. Persons staying on the territory of the Republic of Poland are obliged to undergo mandatory vaccinations under the Protective Vaccination Programme (PSO - Program Szczepień Ochronnych). This program is announced at the end of each October, applies to the following year, and as issued in the form of a communication by the Chief Sanitary Inspector. The programme was published on 16 October 2019 has been in force since 2020. In Poland, vaccinations are considered the most important preventive measures in the field of preventing the spread of infectious diseases, such as tuberculosis, poliomyelitis, measles, chickenpox, hepatitis B, pertussis and diphtheria. Vaccines are also considered as part of the prevention of foetal defects (rubella vaccination) and the 
fight against cancer risk (vaccination against hepatitis B and HPV infections).

Since 2017, the state of vaccinations in Poland has good, even very good. Two years earlier, the vaccination status ranged from $96.7 \%$ to $99.4 \%$ for most vaccinations [24]. In 2017, vaccination at the provincial level varied and ranged from $93.6 \%$ to $99.6 \%$, with the exception of tuberculosis, which ranged from $89.6 \%$ to $94.0 \%$ ) [25] and measles (93\%). Compulsory population vaccinations exceeding $90.0 \%$ for vaccinations are sufficient to achieve community immunity against most diseases, but not against measles, for which the WHO believes the safe vaccination threshold to be $95 \%$. Therefore, one can carefully draw conclusions that 2017 marked a breakthrough in terms of the risk arising from inadequate measles vaccination in Poland. Insufficient vaccination in Poland may be caused by:

- improper implementation of the vaccination programme due to negligence in medical facilities (rarely);

- lack of vaccines (happens rarely);

- postponing vaccination for medical reasons (diseases, cancer, immunosuppressive therapy, etc.);

- non-attendance for vaccine appointments;

- refusal to vaccinate.

With the exception of a few cases, the reasons for worse vaccination in Poland are caused by non-attendance for vaccine appointments or refusing vaccination. Nonattendance for vaccine appointments or written / oral refusal is qualified as an evasion of legal vaccination obligations (vaccination avoidance). In 2010, there were 3,437 such cases, in $2011-4,689,2012-5,340,2013-7,248,2014-12,681$, 2015 - 16,689, 2016 - 23,147, 2017 - 30,090, 2018 - 40,342, and in 2019 - 48,609 cases of vaccination avoidance. In the period 1 January - 31 March 2019 there were already 42,239 avoidance cases, i.e. over 12 times more than in the whole of 2010 [26]. Available data on refusals of preventive vaccinations in the first quarter of 2020 do not reflect the actual situation because the implementation of mandatory preventive vaccinations was suspended in Poland from 1 March 2020 to 17 April 2020 by the decision of the Minister of Health due to the COVID-19 pandemic. Repeal cases calculated per 1,000 people aged $0-19$ were: 0.7 in $2012,0.97$ in 2013, 1.71 in 2014, 2.3 in 2015, 3.2 in 2016, 4.1 in 2017 and 5.5 in 2018, as well as 6.6 in 2019 [26]. In 2019, this indicator was the highest in the Silesian province $-12 / 1,000$, the lowest in the Świętokrzyskie province - 0.8/1,000 inhabitants) [27].

Vaccines - composition and controversy. Vaccines are not homogeneous substances in terms of their composition. Chemically, they are mixtures of highly heterogeneous groups of compounds. The typical vaccine portions includes: 1) antigen(s) that stimulate the immune response:

- as live microorganisms with weakened virulence (attenuated);

- as fragments of a microbial structure or as microorganism metabolites;

2) adjuvants that modulate the immune response and / or keep the antigen at the injection site; adjuvants are usually aluminum compounds - hydroxide, sulfate, phosphate salts (for example calcium phosphate) or oil-water emulsions;

3) excipients and stabilizing compounds added to protect the antigenic material against high or low temperatures, and to prevent adhesion to the walls of the package: sugars (sucrose, lactose), amino acids (glycine, glutamic acid, monosodium glutamate), proteins (gelatine, albumin);

4) preservatives (only applicable to vaccines not containing live / attenuated microorganisms); they are thiomersal, phenol, 2-phenoxyethanol, formaldehyde;

5) trace amounts of substances remaining after the production process, e.g. yeast protein, chicken egg protein, beta propiolactone, antibiotics, formaldehyde and glutaraldehyde.

Antigens, adjuvants, preservatives and substances remaining as trace impurities appearing during the production process raise the most objections. Hypothetically present impurities which not reported by the producer, e.g. bacteria, viruse, or - as propaganda claims - an intentionally introduced increase in the number of cancer cases in order to depopulate the world. Fragments of foreign genetic material are also of great concern to the public. Most of the allegations against vaccines can be presented in the form of the following six thematic groups:

1) non-compliance of the composition with the declared content of the vaccine:

- presence of additional genetic material, e.g. 'Alzheimer's genes';

- uncontrolled additional contaminants (organic, e.g. bacteria, viruses, cellular components of the medium, and proteins, as well as inorganic components);

- presence of mutated cells derived from the medium;

2) the composition of the vaccines violates the religious feelings of various population groups, e.g. allegations of vaccines from the cells from aborted foetuses, foreskin cells, pig tissue);

3) the components of the vaccines are toxic, thus causing the described and known side- effects, regardless of the dose used, e.g. mercury, aluminum;

4) vaccines provoke the appearance of unpublished biological effects, e.g. loss of fertility, Alzheimer's disease, stimulation of carcinogenesis, shortening human life, 'reducing intelligence;

5) vaccinations are not necessary because diseases, through natural evolution and increasing population resistance, 'disappear' by themselves;

6) vaccinations are not necessary because improving both living conditions and hygiene have a greater impact on improvement of the epidemiological situation than vaccinations.

Many of these arguments, especially those regarding the presence of undisclosed admixtures, including biological (e.g., foreign genetic material), are unfounded after taking into account the provisions on the current production regime and multi-stage vaccine safety control procedures that are required in Poland and the EU. The problem, however, is that propaganda against vaccines often completely negates the integrity and competence of everyone: scientists and producers, as well as the institutions that control vaccine safety. At all stages of production vaccines undergo over 500 different qualitative tests [28], including routine composition testing for microbial contamination, which includes bacterial and fungal, spiroplasmic, rickettsial and viral contamination. In order to exclude the presence of viral contaminants, in vivo and in vitro tests for the potential presence of viruses, methods such as PCR and transmission electron microscopy 
techniques are used. Methods for analyzing vaccine metagenome are currently being implemented [28].

EU law requires all vaccine excipients to be publicly disclosed. In Poland, vaccines cannot contain and do not contain substances that are not listed in the Summary of Product Characteristics (SmPC) published on the website of the Office for Registration of Medicinal Products, Medical Devices and Biocidal Products, or on the website of the European Medicines Agency.

Drugs and vaccines approved for use in Poland must obtain the consent of the President of the Office for Registration of Medicinal Products, Medical Devices and Biocidal Products. Such acceptance is based on documentation that must meet the requirements of art. 10 of the Act of 6 September 2001, Pharmaceutical Law (Journal of Laws, 2017, Item 2211, as amended), or conditions specified by the Council of the European Union or the European Commission. The laboratory of the Sera and Vaccine Research Institute of the National Institute of Public Health - National Institute of Hygiene (NIZP-PZH) is responsible for the safety of vaccines in Poland. This laboratory carries out the tasks for the National Medicines Control Laboratory (OMCL) belonging to the Network of Official Medicines Control Laboratories (OMCL). This network is coordinated by the European Directorate for Drug Quality (EDQM - European Directorate for the Quality of Medicines), a non-governmental entity acting on behalf of the Council of Europe. Its task, among others, is to develop official drug production and quality control standards in all countries that are signatories to the European Pharmacopoeia, ensuring the usefulness of certificates and control of drug and vaccine manufacturers.

The laboratory of the Institute of Sera and Vaccine Research(NIZP-PZH) is accredited by the Polish Centre for Accreditation (AB509) and EDQM (EDQM / MJA100 certificate). Vaccines used in Poland are therefore in accordance with the standards approved by the European Union.

All additives that are components of the vaccines are in acceptable doses that are considered safe for the health of children and adults. These substances are the cause of unfair and aggressive criticism concerning vaccines and vaccinations. Among the substances present as adjuvants, preservatives, excipients and stabilizers, as well as substances remaining after the production process, the biggest emotions are evoked by the following substances:

Mercury (Hg) in vaccines. Opponents of vaccines usually mention thiomersal - (Ethyl(2-mercaptobenzoato-(2-)-O,S) mercurate(1-) sodium) - a preservative present in trace amounts in some vaccines since the 1940s. After 1999, due to public concern, the US removed thiomersal from their vaccines for children, and after 2002, from all vaccines. Currently in Poland, thiomersal is included only in the DTP vaccine and its equivalents without pertussis component [29]. In public opinion, thiomersal present in vaccines may cause autism. However, there is no scientific evidence for such a causal relationship. After the abandonment of mercury in vaccines in the US, autism rates did not decrease, which is confirmation that the use of thiomersal and the appearance of autism are unrelated [30].

Thiomersal is not accumulated in the human body, it is metabolized to ethylmercury and thiosalicylate, with a halflife in blood is 3-7 days [28]. Thiomersal content in vaccines corresponds to $12.5 \mu \mathrm{g}-25 \mu \mathrm{g} \mathrm{Hg}$ (or 0.0125-0.025 mg Hg) per $0.5 \mathrm{ml}$ dose [29]. For comparison, the mercury content of many foods is associated with a significantly higher exposure. The permissible mercury content in 'fishery products' mentioned in Directive 2001/22 / EC, ranges from $0.5 \mathrm{mg} / \mathrm{kg}$ to $1 \mathrm{mg} / \mathrm{kg}$ $[31,32]$, in mammalian meat $-0.03-0.05 \mathrm{mg} / \mathrm{kg}$ [32], in milk and dairy product $-0.01 \mathrm{mg} / \mathrm{kg}$ [32], in vegetables and cereals $-0.02 \mathrm{mg} / \mathrm{kg}$ [32] and in mushrooms $-0.05 \mathrm{mg} / \mathrm{kg}$ [32]. Mercury is also found in various medicinal preparations used in unconventional medicine (often approved by vaccine opponents), especially in homeopathic compounds [33-35, and the fact of administration parenteral mercury preparations (LEHNING, Mercurius solubilis No. 39 [35]) is not criticized by opponents of evidence-based medicine.

Aluminum compounds (Al). Aluminum compounds are a physiological component of human plasma with a concentration in the range of $1-2 \mathrm{ng} / \mathrm{ml}$ of blood $(1-2 \mu \mathrm{g} / \mathrm{l})$ [36]. The half-life of aluminum elimination from the human body is about 24 hours [37]. The aluminum content of single doses of vaccines is in the range $0.25-0.85 \mu \mathrm{g}$.

In 2012, the WHO World Advisory Committee on Vaccine Safety (GACVS) announced that the administration of a small amount of aluminum in vaccines was not dangerous [37]. The belief that an amount of aluminum does not pose a health risk is based on the knowledge that exposure to aluminum administered in vaccines is definitely lower than the risk arising from exposure to aluminum present in food, which until then had not been controversial. The main source of aluminum compounds for humans is food. The presence of aluminum in foods ranges from 0.04 to $70 \mathrm{mg} / \mathrm{kg}$ or $\mathrm{mg} /$ liter of product [38] (baby food approx. $0.04 \mathrm{mg} / \mathrm{l}$, dairy mixtures for babies approx. $0.225 \mathrm{mg} / \mathrm{l}$, cucumbers $-0.4-2.0 \mathrm{mg} / \mathrm{kg}$, strawberries - 0.56-2.42 $\mathrm{mg} / \mathrm{kg}$, poultry $-1.0-5.0 \mathrm{mg} / \mathrm{kg}$, beef $-2.0-1.0 \mathrm{mg} / \mathrm{kg}$ and black currant up to $70 \mathrm{mg} / \mathrm{kg}$ ). A 4-month-old infant takes $0.03-0.05 \mathrm{mg} \mathrm{Al} /$ day with milk [36]. A daily dose of aluminum $<2 \mathrm{mg} / \mathrm{kg}$ of body weight is considered safe [37].

Opponents of vaccination believe that the presence of aluminum in vaccines causes long-term health complications, such as Alzheimer's disease $[39,40]$, microcephaly in foetuses and autism, but these allegations have not been scientifically confirmed [40].

Formaldehyde. Formaldehyde is present in vaccines containing inactivated pathogens. It is used to inactivate microorganisms that are potentially biological contaminants, and vaccinations contain only trace amounts of formaldehyde ( $\leq 0.1 \mathrm{mg}$, i.e. $\leq 100 \mu \mathrm{g}$ per dose of vaccine).

Formaldehyde is a chemical compound present in the body of a healthy person, which is a metabolite of thymidine, purine and some amino acids. The physiological concentration of this substance in serum ranges from 0.46 to $0.87 \mu \mathrm{g} / \mathrm{ml}$ (0.46-0.87 mg/l) [41].

Formaldehyde is present in many cosmetics, e.g. shampoos or makeup preparations, it is also a natural (i. e. not resulting from human interference!) component of many food products. Its average content in these products ranges from [41, 42]: $3.3 \mathrm{mg} / \mathrm{l}$ in cow's milk, $4.6 \mathrm{mg} / \mathrm{kg}$ in beef, $6.3-22.3 \mathrm{mg} / \mathrm{kg}$ in apples, $15.3 \mathrm{mg} / \mathrm{kg}$ in pears up to $16.3 \mathrm{mg} / \mathrm{kg}$ in bananas.

Formaldehyde is also present in drinking water with a permissible concentration in water intended for human consumption of $0.050 \mathrm{mg} / \mathrm{l}$, or $50 \mu \mathrm{g} / \mathrm{l}$ [43]). 
The WHO states that the acceptable daily human consumption of formaldehyde is $0.15 \mathrm{mg} / \mathrm{kg}$ body weight [44].

Polysorbate 80. This is a synthetic non-ionic detergent used as an emulsifier or preservative, used, among others, in the food and cosmetics industries. As an addition, it is present primarily in ice cream, cheese and cottage cheese, jellies, ready desserts, ready sauces and soups, chewing gums, pharmaceutical preparations (as a component of tablet glazing coatings), and in the solutions of some biological drugs, e.g. infliximab (Zessly). It also stabilizes solutions of drugs added to parenteral nutrition mixtures.

Anti-vaccination movements suggest that the polysorbate present in vaccines causes 'disorders of genital development' [45], and they also refer to publications that this substance affects $E$. coli bacteria found in the intestine, which may be related to the pathogenesis of Lesniowski-Crohn disease [46].

The content of polysorbate 80 in vaccines is definitely small and a single dose of HPV vaccine contains only 50 micrograms of polysorbate 80 , while the acceptable daily intake is $25 \mathrm{mg} / \mathrm{kg}$ body weight. (total of 20, 40, 60, 65 and 80 polysorbates) [47]. For example, the content of polysorbate 80 in ice cream reaches $0.5 \%(\mathrm{v} / \mathrm{v})$ [29], which produces up to $170 \mathrm{mg}$ of this compound in a typical ice cream cone [48].

Monosodium glutamate. In the human body, this is a precursor, among others, of the neurotransmitter glutamine. Excess of this neurotransmitter causes damage to nerve cells.

Opponents of vaccination suggest that excess glutamate may be the causative agent of degenerative diseases, such as amyotrophic lateral sclerosis, Parkinson's disease and Alzheimer's disease.

Glutamate is a natural ingredient present in meat, fish, cereal products and vegetables, and in free form - in frequently consumed foods, such as milk, potatoes, tomatoes, cheese. It can also be used as a food additive to enhance taste, and it is legalized in the EU under the code name E621. The permissible content of this compound in food products is $10 \mathrm{~g} / \mathrm{kg}$, individually or in combination (calculated as glutamic acid) [49]. Its content in the MMRV vaccine measles-mumps-rubella-varicella produced by Merck Sharp \& Dohme, is $0.38 \mathrm{mg}$ in a single dose of vaccine [50].

Gelatine. Gelatine present in vaccines performs a stabilizing function and protects vaccine antigens against temperature changes. Only highly hydrolyzed, highly purified pork gelatine is used in vaccines. The content of hydrolyzed gelatine in a single dose of MMR II vaccine against measles, mumps and rubella is $14.5 \mathrm{mg} /$ dose [50].

According to the arguments presented by opponents of vaccination, gelatine is harmful, but there are no specific allegations suggesting that it causes specific negative health effects.

There is no evidence that such hydrolyzed gelatine poses any threat to humans, including allergenicity.

Gelatine is present as a thickener and a component of the capsule shell in many drugs available in Poland. It is also used as a drug given by intravenous infusion (e.g. GELOPLASMA solution for infusion - Fresenius Kabi France, Gelaspan 4\% - Aesculap Chifa, Gelofusine (gelatine + sodium (sodium chloride)) in patients with a negative protein balance, including patients with acute blood loss. Routine doses of Gelaspan 4\% are 500-1,000 ml / 24 hours (20-40 g hydrolyzed intravenous gelatine) [51].

Non-substantive arguments - denying the sense and integrity of scientific papers and / or citing secret findings of scientists, reports of 'well-informed persons', 'secret documents' and 'obvious truths'. In addition to substantive arguments or seemingly logical arguments, e.g. discussion about the adverse effects of mercury, aluminum or formaldehyde on the human body, but without taking into account the real doses of these substances, opponents of vaccination cite information classified by them as: 'general knowledge', results of some mysterious researches and observations conducted by unknown persons, groups of scientists and 'obvious truths'. These allegations include the following:

- Vaccinations increase the incidence of infectious diseases. 'In 2012, whooping cough was so widespread throughout America, the number of cases doubled compared to 2011, that epidemiologists and health services even confirmed that the reason for this could be a vaccine.' [52];

- Pertussis vaccine increases the risk of asthma by six times [52];

- There is no need for vaccination against tetanus, regardless of the patient's age and place of residence [52];

- Thousands of cases of sudden loss of consciousness within 24 hours, muscle aches and weakness, Guillain-Barré disease, chronic fatigue, 'facial paralysis', encephalitis, rheumatoid arthritis, lupus, blood clots, optic neuritis, multiple sclerosis, strokes, 'heart attacks and other serious health problems, including deaths', were observed after application of the HPV vaccine [52];

- In the USA, there is a government database containing many thousands of case reports of children who have been injured or died as a result of vaccination complications [53];

- There are many contraindications to vaccination, but doctors do not talk about it [34];

- Mortality and morbidity would decrease spontaneously, even if vaccines were not applied [53];

- Vaccines are used to depopulate humanity [54];

- Most cancers are 'caused by vaccines' [55];

- All vaccines are contaminated with something that causes autism, but also a 'cancer epidemic' [56];

- Nagalase protein enzyme is intentionally added to the composition of vaccines. Nagalase (alpha-Nacetylgalactosaminidase) hinders the binding of vitamin $\mathrm{D}$ and $\mathrm{Gc}$ protein and causes vitamin D deficiency in human body [57];

- Companies producing oncological drugs benefit from adding nagalase to vaccines, because nagalase causes 'tumour growth', which increases the demand for oncological drugs [57];

- 'According to scientific studies', 'HPV vaccines also cause ovarian failure and, consequently, infertility' [58];

- Vaccination 'reduces intelligence' and causes autism [59];

- Most drugs and vaccines are manufactured in China, India, Vietnam and Korea, where vaccines are contaminated due to technology imperfections [59];

- Merck vaccines are contaminated with the virus that caused the AIDS epidemic in the USA [60];

- The US government has revealed that the hepatitis B vaccine causes lupus, and that the vaccine given to every child in the United States after birth can trigger the development of multiple sclerosis [61] 
- According to CIA statistics, life expectancy decreases as the vaccination rate increases;

- New vaccines are contaminated with genetically modified DNA;

- $61 \%$ of all human cancers (as found at autopsy) contain the SV40 monkey virus, which can be referred to the polio vaccine of the 1950s and 1960s [62]. Although it is a fact that this virus is associated with the etiopathogenesis of human cancers [63], the numbers quoted are significantly overstated - erroneous positive results in studies using alleged inaccurate virus identification methods [64]). The observation of cancer dynamics does not support the thesis that possible SV40 contamination was common and could have increased the number of cancer cases recorded in humans [45]; in addition, SV40 DNA sequences are only present in mesothelioma, some brain tumours, osteosarcoma and non-Hodgkin's lymphoma (NHL)) but is not present in most cancers [64]);

- Treatment of diseases and their complications is a much larger source of income for pharmaceutical companies than vaccine production alone [65];

- In 2009, the Finnish Minister for Health said 'A/H1N1v vaccines were designed to reduce the population' [62];

- Vaccines are to turn the free man into a slave. 'Vaccinated are children from poor, uneducated, lumpen proletariat and coloured families. Children from rich, educated and white families are not vaccinated.' [45];

- Vaccination campaigns in poor countries are sham actions organized by hostile foreign States that collect intelligence, or weaken people living in a given area (rumors of this type have been spread in Africa and Pakistan $[66,67])$.

Elements of religious rhetoric in anti-vaccine propaganda. Relying on religious aspects in the context of vaccination and vaccine composition allows reaching specific religious groups and strengthening the negative message. Such propaganda is addressed primarily to people with fundamentalist views. Fundamentalists are often prone to propaganda and at the same time are very active in combating activities that harm their understanding of religion. Religious arguments used by anti-vaccination movements include the following statements:

Vaccines are produced on the basis of cells from aborted foetuses [68], which is a very sensitive topic for many religious groups. Hindu, Protestant, Muslim and Jewish communities essentially oppose abortion for religious reasons. The Catholic Church allows the temporary use of vaccines produced using foetal tissues obtained as a result of abortion if it is to protect children against disease, and when no other alternative methods are currently available [69]. In Poland, vaccines produced using two human cell lines are currently in use: the WI-38 cell line obtained in the United States in 1964 from a miscarried 12-week-old female foetus (used for the production of rubella vaccine), and the MR-C5 line, obtained in 1966 in the UK from a 14-week-old miscarriage of a male foetus and currently used to produce a vaccine against hepatitis A and varicella [70]. Vaccine propaganda uses the term 'interrupted foetuses' but does not mention the official guidelines of the Church [71]. Meanwhile, the Pontifical Academy of Life emphasizes that 'the use of vaccines does not mean cooperation with voluntary abortion' [72], and 'the cell lines used in current vaccines are very distant from the old ones and do not impose any ethical burden' [72].
Vaccinations threaten God's world order [71]. ChristianProtestant congregations believe that vaccination is an expression of 'improper meddling in God's work' [71].

Vaccines contain material propagated on pig-derived cells. This is a sensitive topic for religions such as Judaism and Islam [73].

Among the animal cells, the source of cells for the production of vaccines for humans is the Vero cell line, which was isolated in 1962 from the kidneys of an adult African monkey Chlorocebus aethiops. It is used in the production of polio, rabies and rotavirus vaccines available in Poland, as well as US vaccines against rotavirus, polio, Japanese encephalitis and chickenpox. Other cell lines, e.g. avian or mouse cells, are rarely used, and such vaccines are not available in Poland for human vaccination. Vaccines produced on different animal lines are used instead for veterinary prophylaxis, e.g. the Rabivac anti-rabies vaccine produced on the line from the hamster kidney BHK-21, a vaccine against parvovirosis on the canine line and vaccine against Post Weaning Multisystemic Wasting Disease (PMWS) on the pig kidney line. Pig cell lines are not used to produce human vaccines [74].

Vaccines are produced on the basis of cells derived from the foreskin [75]. This topic is sensitive for orthodox Jews and is not true.

Vaccines contain gelatine obtained from the tissues of the cow's body. This is not true. Only hydrolyzed pork gelatine is used in vaccines. This is a sensitive topic for Hindus for whom the cow is sacred, and therefore insist on vaccines without cow material [76].

Vaccines contain gelatine derived from pigs. This is true. This is sensitive topic for radical followers of Judaism and the religion of Islam.

Currently, governments in many countries allow parents to waive the obligation to vaccinate for religious reasons. This applies not only to many Asian and African countries, but also to the USA, where in most States, except Mississippi, e.g. in West Virginia and California, such exemptions are also practiced) [77].

Many countries, including European countries, do not impose an obligation to vaccinate children. Vaccinations are voluntary in, among others, Belgium, Germany, Norway, Portugal, Romania and the UK [78]). Religious arguments for vaccines in these countries can have a particularly negative impact on the epidemiological situation. The religious aspect is undoubtedly one of the arguments for the development of opposition to vaccination also in Poland, where only 59.3\% of respondents claim that vaccination is consistent with their religious beliefs. This is the lowest result in the entire EU [79].

\section{CONCLUSIONS}

In recent years, the activity of movements against vaccination has increased significantly and their propaganda, through its negative impact on social attitudes, threatens to destabilize the epidemiological situation in Poland. The slogans propagated by anti-vaccination movements are usually based on easily proven erroneous theories and lies, although there are also arguments expressing belief in some conspiracy of governments, politicians and vaccine manufacturers, or the incompetence of scientists and practitioners.

Many opponents of vaccines refer to selected religious arguments, addressed primarily to people with fundamentalist 
views. Although these arguments are based on unverified information or are intentionally misleading, such slogans have a strong impact on selected groups in societies. However, understanding the arguments of the anti-vaccine activists is necessary in order to implement effective methods of opposing such mistaken attitudes and beliefs.

\section{REFERENCES}

1. Plans-Rubió P. Evaluation of the establishment of herd immunity in the population by means of serological surveys and vaccination coverage. Hum Vaccin Immunotherap. 2012; (8)2: 184-188. doi.org/10.4161/ hv. 18444

2. Elam-Evans LD, Yankey D, Singleton JA, Kolasa M. National, state, and selected local area vaccination coverage among children aged 19-35 months - United States, 2013. MMWR Morb Mortal Wkly Rep. 2014; 63(34): 741-748

3. Ospa prawdziwa [Smallpox]. https://pl.wikipedia.org/wiki/Ospa_ prawdziwa (access: 2020.05.01). [in Polish]

4. WHO commemorates the 40th anniversary of smallpox eradication. https://www.who.int/news-room/detail/13-12-2019-who-commemorates-the-40th-anniversary-of-smallpox-eradication (access: 2020.05.01).

5. Dlaczego szczepienia są ważne? [Why are vaccinations important?] https://szczepienia.pzh.gov.pl/wszystko-o-szczepieniach/plusy-iminusy-szczepionek/2/\#dlaczego-szczepienia-sa-wazne--(access: 2020.05.01). [in Polish]

6. Louis Pasteur. https://pl.wikipedia.org/wiki/Louis_Pasteur (access: 2020.05.01). [in Polish]

7. Historia szczepień ochronnych. [History of preventive vaccinations] http://nfz-poznan.pl/getAttach.php?AttachID=1181\&AttachCt rl=704089 (access: 20202.05.01). [in Polish]

8. Almroth Wright. https://es.wikipedia.org/wiki/Almroth_Wright (access: 2020.05.01).

9. Richard Pfeiffer. https://pl.wikipedia.org/wiki/Richard_Pfeiffer (access: 2020.05.01). [in Polish]

10. Rudolf Weigl. https://pl.wikipedia.org/wiki/Rudolf_Weigl (access: 2020. 05.01). [in Polish]

11. Szczepionka BCG [BCG vaccine]

https://pl.wikipedia.org/wiki/Szczepionka_BCG (access: 2020.05.01). [in Polish]

12. Davidson T. Vaccines: History, Science, and Issues. ABC-CLIO, LLC Santa Barbara, California, 2017; 44.

13. Wikipedia.pl. Hilary Koprowski. https://pl.wikipedia.org/wiki/Hilary_ Koprowski (access: 2020.05.01). [in Polish]

14. Wikipedia.en. Jonas Salk. https://en.wikipedia.org/wiki/Jonas_Salk (access: 2020.05.02).

15. Albert Sabin. https://en.wikipedia.org/wiki/Albert_Sabin (access: 2020.05.02).

16. John Franklin Enders. https://en.wikipedia.org/wiki/John_Franklin_ Enders (access: 2020.05.02).

17. Maurice Hilleman. https://en.wikipedia.org/wiki/Maurice_Hilleman (access 2020.05.02).

18. Szczepionka. [Vaccine] https://pl.wikipedia.org/wiki/Szczepionka (access: 2020.05.02). [in Polish]

19. Rotavirus Vaccines. https://www.sciencedirect.com/topics/ neuroscience/rotavirus-vaccine (access: 2020.05.02).

20. Szczepionka przeciw WZW B. [Hepatitis B vaccine] https://szczepienia. pzh.gov.pl/szczepionki/wzw-b/4/\#jakie-znamy-rodzaje-szczepionekprzeciw-wzw-b- (access: 2020.05.02). [in Polish]

21. Szczepionka przeciw HPV. [HPV vaccine] https://szczepienia.pzh.gov. $\mathrm{pl} /$ szczepionki/hpv/ (access: 2020.05.02). [in Polish]

22. Magdzik W. Choroba Heinego i Medina - porażenie dziecięce -poliomyelitis - polio. Rozkwit i agonia choroby w dwudziestym wieku [Heine-Medina disease - children's Palsy - poliomyelitis - polio. Flow and agonia of the disease in the twentieth age] Przegl Epidemiol. 2002; 56: 519-530. [in Polish]

23. Narodowy Instytut Zdrowia Publicznego - Państwowy Zakład Higieny. O szczepionce. Jakie rodzaje szczepionek przeciw poliomyelitis są dostępne w Polsce? [National Institute of Public Health - National Institute of Hygiene. About the vaccine, which poliomyelitis vaccines are available in Poland?] http://szczepienia.pzh.gov.pl/szczepionki/ poliomyelitis/4/ (access: 2020.04.06). [in Polish]

24. Wojtyniak B, Goryński P. editors. Sytuacja zdrowotna ludności Polski i jej uwarunkowania. [Health situation of the Polish population and its determinants.] Narodowy Instytut Zdrowia Publicznego-Państwowy Zakład Higieny, Warszawa 2016; 205. [in Polish]

25. Wojtyniak B, Goryński P. editors. Sytuacja zdrowotna ludności Polski i jej uwarunkowania. [Health situation of the Polish population and its determinants.] Narodowy Instytut Zdrowia Publicznego-Państwowy Zakład Higieny, Warszawa 2018; 254. [in Polish]

26. Narodowy Instytut Zdrowia Publicznego-Państwowy Zakład Higieny. Jaka jest liczba uchyleń dotyczących szczepień obowiązkowych? [National Institute of Public Health - National Institute of Hygiene. What is the number of refusals for compulsory vaccinations?] http:// szczepienia.pzh.gov.pl/faq/jaka-jest-liczba-uchylen-szczepienobowiazkowych/ (access: 2020.05.06). [in Polish]

27. Liczba odmów szczepień obowiązkowych w 2019 roku z podziałem na województwa [Number of refusals of compulsory vaccinations in 2019 by voivodship] https://szczepienia.pzh.gov.pl/wp-content/ uploads/2020/04/Odmowy-szczepie\%C5\%84-Mapa_2019_1100px. jpg (access: 2020.05.08). [in Polish]

28. Seib KL, Dougan G, Rappuoli R. The key role of genomics in modern vaccine and drug design for emerging infectious diseases. PLoS Genetics. 2009; 5(10): e1000612. doi: 10.1371/journal.pgen.1000612

29. Gołoś A, Lutyńska A. Tiomersal w szczepionkach - aktualny stan wiedzy. [Thiomersal in vaccines - current state of knowledge.] Przegl Epidemiol. 2015; 69: 157-161. [in Polish]

30. Fombonne E.: Thiomersal disappears but autism remains. Arch Gen Psychiatry. 2008; 65(1): 15-16. doi:10.1001/archgenpsychiatry.2007.2

31. Commission Regulation (EC) No 466/2001 of 8 March 2001 setting maximum levels for certain contaminants in foodstuffs (Text with EEA relevance)

32. Regulation of the Minister of Health of 13 January 2003. Maximum levels of chemical and biological contaminants that may be found in food, food ingredients, permitted additives, processing aids or on the surface of food. OJ 2003 No. 37 item 326.

33. BOIRON. Mercurius Solubilis $9 \mathrm{CH}$ granulki $4 \mathrm{~g}$ [BOIRON. Mercurius Solubilis $9 \mathrm{CH}$ granules $4 \mathrm{~g}$ ] https://www.aptekawsieci.pl/ $\mathrm{pl} / \mathrm{p} / \mathrm{BOIRON}-\mathrm{Mercurius}-S o l u b i l i s-9-\mathrm{CH}$-granulki-4-g/938 (access: 2020.03.23). [in Polish]

34. Heel. Poradnik Terapeutyczny. [Heel. Therapeutic guide]. Instytut Psychosomatyczny. Warszawa 1994; 56-112. [in Polish]

35. Lehning Laboratories Mercocurius Solubilis Nr 39 https://www.lehning. pl/lehning-mercocurius-solubilis (access: 2020.03.23). [in Polish]

36. Krewski D, Yokel RA, Nieboer E, Borchelt D, Cohen J, Harry J, Kacew S, Lindsay J, Mahfouz AM, Rondeau V. Human health risk assessment for aluminium, aluminium oxide, and aluminium hydroxide. J Toxicol Environ Health B Crit Rev. 2007; 10 Suppl 1: 1-269. doi: $10.1080 / 10937400701597766$

37. WHO. Global Vaccine Safety. Report of GACVS meeting of 6-7 June 2012, published in the WHO Weekly Epidemiological Record on 27 July 2012. World Health Organization, Geneva 2012.

38. Zuziak J, Jakubowska M. Glin w otoczeniu i jego wpływ na organizmy żywe. [Aluminum in the environment and its impact on living organisms.] Analit. 2016; 2: 110-120. [in Polish]

39. WolneMedia.net. Wpływ szczepionki przeciw grypie na twój mózg. [Impact of influenza vaccine on your brain.] http://wolnemedia. net/wplyw-szczepionki-przeciw-grypie-na-twoj-mozg/ (access: 2020.03.23). [in Polish]

40. Ekspert antyszczepionkowy w sejmie straszy aluminium. Nie jest lekarzem, nie pracuje ze szczepionkami. O co chodzi? [An antivaccination expert in the parliament threatens aluminum. He's not a doctor, he doesn't work with vaccines. What is going on?] https:// www.focus.pl/artykul/ludzie-choruja-po-szczepionkach-kontragruba-przesada-antyszczepionkowcy-w-sejmie-190108024935 (access: 2020.03.23). [in Polish]

41. Luo W, Li H, Zhang Y, Ang CY. Determination of formaldehyde in blood plasma by high-performance liquid chromatography with fluorescence detection. J Chromatogr B Biomed Sci Appl. 2001 Apr 5; 753(2): 253-7.

42. Wahed P, Razzaq MA, Dharmapuri S, Corrales M. Determination of formaldehyde in food and feed by an in-house validated HPLC metod. Food Chemistry 2016; 202: 476-483. doi: 10.1016/j. foodchem.2016.01.136. Epub 2016 Feb 2.

43. Rozporządzenie Ministra Zdrowia z dnia 29.03.2007 r. w sprawie jakości wody przeznaczonej do spożycia przez ludzi - Załącznik nr 4. Kancelaria Sejmu RP. Dz.U. 2007 nr 61 poz. 417. [Regulation of the Minister of Health of March 29, 2007 on the quality of water intended for human consumption - Annex 4. Chancellery of the Sejm of the Republic of Poland. OJ 2007 No. 61 item 417.] [in Polish]

44. EU Regulation: Formaldehyde Product-type 02 (Disinfectants and algaecides not intended for direct application to humans or animals). 
Regulation (EU) No 528/2012 concerning the making available on the market and use of biocidal products, Germany, 2017.

45. Jaśkowski J. Osiem najbardziej szkodliwych leków na świecie [Eight of the most harmful drugs in the world] http://alexjones.pl/aj/ajtechnologia-i-nauka/aj-medycyna/item/90054-osiem-najbardziejszkodliwych-lekow-na-swiecie (access: 2020.03.26). [in Polish]

46. Roberts CL, Keita AV, Duncan SH, O'Kennedy N, Söderholm JD, Rhodes JM, et al. Translocation of Crohn's disease Escherichia coli across M-cells: contrasting effects of soluble plant fibres and emulsifiers. Gut. 2010; 59(10): 1331-1339. doi: 10.1136/gut.2009.195370. Epub 2010 Sep 2.

47. European Food Safety Authority: Scientific Opinion on the reevaluation of polyoxyethylene sorbitan monolaurate (E 432), polyoxyethylene sorbitan monooleate (E 433), polyoxyethylene sorbitan monopalmitate (E 434), polyoxyethylene sorbitan monostearate (E 435) and polyoxyethylene sorbitan tristearate (E 436) as food additives. EFSA J. 2015; 13(7): 4152. doi: 10.2903/j.efsa.2015.4152

48. Goff HD. Colloidal aspects of ice cream-A review. International Dairy Journal. 1977; 7(6-7): 363-373. https://doi.org/10.1016/S09586946(97)00040-X (access: 2020.03.26).

49. Commission Regulation (EU) No 1129/2011 of 11 November 2011 amending Annex II to Regulation (EC) No 1333/2008 of the European Parliament and of the Council by establishing a Union list of food additives. Text with EEA relevance.

50. Merck: M-M-R $\mathrm{II}$ (Measles, Mumps, And Rubella Virus Vaccine Live) Description. Merck Sharp \& Dohme Corp., a subsidiary of Merck \& Co., Inc. Revised: 05/2017. uspi-v205c-i-1705r007

51. Braun B. Gelaspan roztwór do infuzji. [Gelaspan solution for infusion] B. Braun Melsungen AG34209 Melsungen, Niemcy, 2018. [in Polish]

52. Dave Mihalovic. 3 szczepionki dla dzieci które powinny być absolutnie zakazane.[3 vaccines for children that should be absolutely banned.] https://wolna-polska.pl/wiadomosci/3-szczepionki-dzieci-ktorepowinny-byc-absolutnie-zakazane-2014-10 (access: 2020.03.26). [in Polish]

53. Bańkowska A. Szczepienia dzieci. Rtęć, autyzm... - tego boją się rodzice. Ekspert obala 14 znanych mitów [Vaccinations of children. Mercury, autism ... - that's what parents are afraid of. The expert refutes 14 known myths] http://wiadomosci.gazeta.pl/wiadomosci/1,114871, 17527244,Szczepienia_dzieci__Rtec__autyzm______tego_boja_sie. html (access: 2020.03.26). [in Polish]

54. Przymus szczepień - podwójne dno depopulacji Słowian [Forced vaccination - double bottom of the Slavs' depopulation] https://www. odkrywamyzakryte.com/przymus-szczepien/ (access: 2020.03.26). [in Polish]

55. Brzoza K. Większość nowotworów powstaje przez szczepionki [Most cancers are caused by vaccines] https://onalubi.pl/rak/wiekszoscnowotworow-powstaje-przez-szczepionki/ (access: 2020.04.14). [in Polish]

56. Zamordowani lekarze odkryli powodujący raka enzym dodawany do wszystkich szczepionek [Murdered doctors have found a cancercausing enzyme added to all vaccines] http://alexjones.pl/aj/aj-nwo/ aj-kartel-farmaceutyczny/item/71786-zamordowani-holistycznilekarze-odkryli-powodujacy-raka-enzym-dodawany-do-wszystkichszczepionek (access: 2020.04.14). [in Polish]

57. Przemysł rakowy czerpie zyski ze wstrzykiwania ludziom poprzez szczepionki cząsteczek nagalazy, które powodują wzrost guzów [The cancer industry benefits from injecting nagalase molecules into humans through vaccines that cause tumors to grow] https://wolna-polska. $\mathrm{pl} /$ wiadomosci/przemysl-rakowy-czerpie-zyski-ze-wstrzykiwanialudziom-poprzez-szczepionki-czasteczek-nagalazy-ktore-powodujawzrost-guzow-2016-09 (access: 2020.04.14). [in Polish]

58. Ogólnopolskie Stowarzyszenie Wiedzy o Szczepieniach Stop-Nop. Socha J. Nie będzie obowiązkowej szczepionki przeciw HPV [There will be no compulsory HPV vaccine] http://stopnop.com.pl/niebedzie-obowiazkowej-szczepionki-przeciw-hpv/ (access: 2020/04.14). [in Polish]

59. „Szczepienia obniżają inteligencję i powodują autyzm”. Skandaliczny wykład na uniwersytecie. Wykład Marii D. Czajkowska-Majewskiej ['Vaccination lowers intelligence and causes autism.' A scandalous lecture at the university. Lecture by Maria D. Czajkowska-Majewska] https://innpoland.pl/135449,szczepienia-obnizaja-inteligencje-ipowoduja-autyzm-skandaliczny-wyklad-na-uniwersytecie (access 2020.04.14). [in Polish]

60. Edmonson S. Wszystkie szczepionki są zanieczyszczone - dosłownie wszystkie! [All vaccines are contaminated - literally all!] http://www.prisonplanet.pl/nauka_i_technologia/wszystkie_ szczepionki_sa,p1313076630 (access: 2020.04.14). [in Polish]

61. Skład szczepionek, czyli o czym lepiej nie informować klienta [Vaccine composition, which is better not to inform the customer about] https:// szczepienia.wybudzeni.com/sklad-szczepionek/ (access: 2020.04.14). [in Polish]

62. Wszystkie szczepionki są zanieczyszczone [All vaccines are contaminated]

http://wolnemedia.net/zdrowie/wszystkie-szczepionki-sazanieczyszczone/ (access: 2020.04.14). [in Polish]

63. Shah KV. SV40 and human cancer: a review of recent data. Int. J. Cancer. 2007; 120(2): 215-223, https://doi.org/10.1002/ijc.22425 (access: 2020.04.14)

64. Carter JJ, Madeleine MM, Wipf GC, Garcea RL, Pipkin PA, Minor PD, et al. Lack of serologic evidence for prevalent simian virus 40 infection in humans. J Natl Cancer Inst. 2003; 95(20): 1522-1530, https://doi. org/10.1093/jnci/djg074 (access: 2020.04.14).

65. Poradnik zdrowej istoty. Lekarze prawie jednomyślni: szczepienia niestety są niebezpieczne!!! [A healthy being's guide. Almost unanimous doctors: unfortunately vaccinations are dangerous!!!] http:// niezdrowybiznes.pl/lekarze-prawie-jednomyslni-szczepienia-niestetysa-niebezpieczne/ (access: 2020.04.20). [in Polish]

66. McNeil DG Jr. Gunmen Kill Nigerian Polio Vaccine Workers in Echo of Pakistan Attacks. The New York Times. 2013. https://www.nytimes. com/2013/02/09/world/africa/in-nigeria-polio-vaccine-workers-arekilled-by-gunmen.html (access: 2020.04.20).

67. Vanderslott S, Roser M. Vaccination. https://ourworldindata.org/ vaccination (access: 2020.04.20).

68. Rudy LR. Do Vaccines Contain Aborted Fetal Tissue? https://www. verywellhealth.com/do-vaccines-contain-aborted-fetal-tissue-260337 (access: 2020.04.20).

69. Moral reflections on vaccines prepared from cells derived from aborted human foetuses http://www.immunize.org/talking-about-vaccines/ vaticandocument.htm (access: 2020.04.20).

70. Gałecki S. Etyczne aspekty szczepionek uzyskiwanych z linii ludzkich komórek zarodkowych. [Ethical aspects of vaccines obtained from human germ cell lines]

https://www.mp.pl/szczepienia/specjalne/100056, etyczne-aspektyszczepionek-uzyskiwanych-z-linii-ludzkich-komorek-zarodkowych (access: 2020.04.27). [in Polish]

71. Pierik R. On religious and secular exemptions: A case study of childhood vaccination waivers. Ethnicities. 2017; 17(2): 220-241. doi: $10.1177 / 1468796817692629$

72. Watykan za szczepionkami. Papieska komisja prosi rodziców o szczepienie dzieci [Vatican for vaccines. The papal commission asks parents to vaccinate their children\} https://www.deon.pl/religia/ kosciol-i-swiat/z-zycia-kosciola/art,37719,watykan-za-szczepionkamipapieska-komisja-prosi-rodzicow-o-szczepienie-dzieci.html (access: 2020.04.27). [in Polish]

73. Toxic Vaccine Ingredients: The Devil is in the Details. https:// childrenshealthdefense.org/news/toxic-vaccine-ingredients-the-devilsin-the-details/ (access: 2020.04.27).

74. Plotkin S. Human Cell Strains in Vaccine Development. https://www. historyofvaccines.org/content/articles/human-cell-strains-vaccinedevelopment (access: 2020.04.27).

75. Baby Foreskin Is Being Used To Make Vaccines. https://vactruth. com/2017/09/28/foreskin-used-in-vaccines/ (access: 2020.04.27).

76. Hindu groups want vaccines without beef gelatine. https://www. thestar.com.my/news/nation/2016/07/28/hindu-groups-want-vaccineswithout-beef-gelatine/\#iokVGUk6kruvc5VI.99 (access: 2020.04.27).

77. Shaw J, Mader EM, Bennett BE, Vernyi-Kellogg OK, Yang YT, Morley C P. Immunization Mandates, Vaccination Coverage, and Exemption Rates in the United States Open Forum Infect Dis. 2018; 5(6): ofy130. doi: 10.1093/ofid/ofyl30PMCID: PMC6016709

78. Bozzola E, Spina G, Russo R, Bozzola M, Corsello G, Villani A. Mandatory vaccinations in European countries, undocumented information, false news and the impact on vaccination uptake: the position of the Italian pediatric society. Ital J Pediatr. 2018; 44(1): 67. doi: 10.1186/s13052-018-0504-y. PMID: 29898770; PMCID: PMC6001041.

79. Larson H, Figueiredo A de, Karafillakis E, Rawal M. State of vaccine confidence in the EU 2018. Publications Office of the European Union, 2018. 